\title{
Strategy to Accelerate Financial Literacy Rate in Indonesia: Best Practices from Selected Countries
}

\author{
Ubaidillah Nugraha ${ }^{1}$ \\ University of Bina Nusantara/University of Indonesia/HSBC Bank
}

\begin{abstract}
In the last 10 years, Indonesia's economy has been climbing up significantly and joined the top 20 biggest economy (G20. It is expected that by 2030, the country will be the 7th largest economy supported by what is called "Demographic Dividend" (Mckinsey, 2012). However, in the paradoxical situation, the country's rating in human development index and inequalityadjusted human development index has been deteriorating overtime contributed by stagnant improvement of several development indicators including of access to education and adult financial literacy. This paper will focus on policy recommendation of financial literacy as part of human development capacity building to address inequality issues using the framework of "Functional View of Public Management" developed by Barzelay and Cortazar (2004) and involving several key experiences from countries such as New Zealand, Australia, Singapore and Brazil.
\end{abstract}

Keywords: Financial Inclusion, Public Management, Inequality, Financial Education and literacy, Public Sector Reform. 


\title{
Strategi Kebijakan Percepatan Tingkat Literasi Keuangan di Indonesia: Studi Praktik Terbaik Beberapa Negara Terpilih
}

\author{
Ubaidillah Nugraha, Universitas Bina Nusantara/Universitas Indonesia/HSBC Bank
}

\section{Pendahuluan: Literasi Keuangan, Paradoks Pertumbuhan dan Kapasitas Manusia}

Indonesia adalah rumah bagi lebih dari 250 juta orang, negara dengan jumlah populasi terbesar ke 4 di dunia. Dalam sepuluh (10) tahun terakhir ekonomi Indonesia telah berkembang secara signifikan sehingga menempatkannya ke dalam kelompok 20 besar ekonomi dunia (G20). Diperkirakan menjelang tahun 2030, Indonesia akan menapaki 7 besar ekonomi dunia terutama dengan berkah bonus demografi (Demographic Dividend), dimana mayoritas penduduk adalah generasi muda produktif berusia di bawah 30 tahun (Mckinsey, 2012)

Akan tetapi, terdapat situasi paradoks dimana seiring dengan kemajuan ekonomi, ranking pengembangan kapasitas manusia baik human development index maupun inequality adjusted human development index ${ }^{2}$ justru mengalami stagnasi dari waktu ke waktu (ranking di atas 100 sejak tahun 2000 untuk kedua indikator tersebut). Salah satu indikator yang mempengaruhi ranking tersebut, salah satunya adalah akses kepada pendidikan dan tingkat literasi (termasuk di dalamnya literasi keuangan) ${ }^{3}$. Livelihood framework ${ }^{4}$ yang diperkenalkan oleh Cameron (2006) menunjukkan bahwa tingkat literasi orang dewasa memiliki pengaruh yang signifikan kepada kehidupan sosial dan keuangan sebagai konsekuensi dari rendahnya literasi.

Kenyataan ini meninggalkan para pemangku kebijakan termasuk di dalamnya otoritas di sektor keuangan, sebuah pekerjaan rumah besar dalam menanggapi paradoks ini. Indonesia dalam kurun waktu 30 tahun terakhir telah kehilangan momentum dari kesempatan oil boom di tahun 70an dan keajaiban Asia (Asia's miracle) di era 90an dikarenakan oleh tata kelola dan korupsi yang merajalela serta ketidaksiapan menghadapi krisis keuangan. Era 20152030 akan menjadi kesempatan ketiga Indonesia dengan adanya dividen demografis yang mana penduduk muda akan menjadi subyek momentum ini. Dibutuhkan kebijakan yang dapat merealisasikan potensi momentum ini, menempatkan masyarakat dalam episentrum pembangunan terutama di era digital. Harapannya adalah bonus demografi tersebut benarbenar akan menjadi dividen bagi bangsa ini termasuk industri keuangan secara khusus karena kualitasnya yang terus meningkat dan memperkokoh industri keuangan itu sendiri.

Paper ini akan memberikan fokus pada rekomendasi strategi kebijakan literasi keuangan sebagai bagian penting dari membangun kapasitas masyarakat Indonesia (human capacity building). Literasi keuangan akan dilihat sebagai perpektif penting dalam kebijakan sektor keuangan di Indonesia, menggunakan pendekatan "Functional view of public management" yang dikembangkan oleh Barzelay and Cortázar (2004) dan melihat beberapa kasus pengalaman dari negara-negara lain seperti Brazil, Selandia Baru, Australia dan Singapura.

\section{Sejarah Singkat Evolusi Industri keuangan Indonesia}

Sektor keuangan di Indonesia telah mengalami evolusi yang dramatis selama 60 tahun terakhir. Menurut Hamada (2003), sistem keuangan Indonesia telah dibangun dari lima (5) fase evolusi. Fase-fase tersebut adalah periode pembentukan/formative (1966-1972), periode kenaikan harga minyak/soaring oil price (1972-1997), periode "reformasi keuangan" (19831991), periode "ekspansi" (1992-1997), periode "restrukturisasi" (1998-2008). Evolusi terkini dikenal dengan periode "Inklusi Keuangan" (2009-).

\footnotetext{
${ }^{2}$ Ranking pengembangan manusia tergambar dalam Human Development Index (HDI) ataupun inequality adjusted human development index yang dikeluarkan oleh UNDP yang bertujuan merubah orientasi fokus pembangunan dari semata kebijakan pertumbuhan ekonomi kepada kebijakan pembangunan manusia.

${ }^{3}$ Visa International melakukan survey literasi keuangan kepada 30 negara dan menempatkan Brazil sebagai negara yang paling progresif di dunia dalam mempercepat tingkat literasi dan menempatkan Indonesia pada peringkat kedua terbawah pada survey (lihat lampiran 2).

${ }^{4}$ Economic Intelligence Unit (EIU) dan Person Education menempatkan Indonesia pada peringkat terbawah (40) dari sisi perkembangan pendidikan (education's progress) berdasarkan kajian "Learning Curve Report" in 2014
} 
Periode formative (1966-1972) ditandai dengan kegiatan sekor keuangan yang sebagian besar mendukung manajemen bantuan luar negeri dimana pada saat itu ekonomi masih tergantung pada bantuan keuangan organisasi internasional dan negara-negara maju. Sementara periode kenaikan harga minyak (1973-1982.) telah banyak mempengaruhi sektor keuangan saat itu yang mana kebijakan moneter ditandai dengan provisi likuiditas kredit Bank Indonesia yang didukung oleh oil boom (Binhadi, 1995). Pemerintah juga mulai mengembangkan lansekap industri keuangan dengan pengembangan pasar modal. Selanjutnya evolusi ditunjukkan dengan periode Financial Reform (1983-1991) yang mana shock harga minyak di awal tahun 90an telah memaksa Indonesia untuk memikirkan kembali kebijakan ekonomi dan keuangannya sepanjang tahun 80an dan awal 90an. Liberalisasi keuangan (Financial liberalization) dilakukan dengan pendekatan pasar dan mengurangi peran dan beban dari negara (Wardhana, 1995). Pemerintah memberikan kesempatan kepada sektor swasta untuk membangun institusi keuangan berdasarkan prinsip pasar melalui deregulasi perbankan 1988. Sejak saat itu, ratusan bank dan institusi keuangan berkembang dan mewarnai pertumbuhan sektor keuangan.

Di era 90 an, sektor keuangan berevolusi kedalam tahap periode ekspansi keuangan (1992-1997). Respon positif dari pihak swasta telah menstimulasi relaksasi dari beragam peraturan untuk memberikan insentif dan mengurangi halangan untuk masuk. Pemerintah mengeluarkan serial kebijakan yang melepaskan hambatan seperti rating dan capitaladequacy ratio. Hal ini menciptakan lingkungan yang bersahabat dalam menjalankan bisnis perbankan yang terkait, akan tetapi di saat yang bersamaan memberikan konsekuensi kepada risiko yang mulai muncul terhadap industri keuangan secara keseluruhan yang puncaknya adalah krisis keuangan 1997. Selama periode krisis, sektor keuangan memasuki fase restrukturisasi (1998-2008).Indonesia adalah salah satu negara yang terhantam krisis paling dalam (Hill, 2000). Beberapa pengamat menggunakan istilah "matinya macan Asia" untuk menggambarkan bencana yang dialami masyarakat Indonesia saat itu. Hampir $40 \%$ dari bank tutup dan indeks saham turun $50 \%$ dalam setahun. Menyusul krisis, Indonesia telah memperkuat fungsi pengawasan dan meminta institusi keuangan untuk memperkuat struktur permodalan untuk mencegah potensi hantaman krisis berikutnya. Wacana untuk perlunya memiliki fungsi pengawasan yang terpisah dari Bank Indonesia mulai dimunculkan.

Dan akhirnya, kondisi terkini sektor keuangan diwarnai kepada upaya untuk menciptakan industri keuangan yang inklusif (2009-saat ini). Saat ini, sektor keuangan berhadapan dengan tantangan ketimpangan dalam masyarakat dalam mengakses dan mendapatkan manfaat dari industri tersebut. Satu dari beberapa faktor penting adalah keterlibatan dan pemberdayaan masyarakat dari berbagai latar belakang baik sosial, ekonomi, gender dan keyakinan ke dalam sistem keuangan secara keseluruhan. Indikator akses keuangan menunjukkan bahwa Indonesia cukup tertinggal dalam hal ini dibandingkan beberapa negara berkembang lainnya (Wu, 2011).

\section{Sektor Keuangan yang Inklusif dan Literasi Keuangan: Definisi, Tujuan dan Manfaat}

Sebuah industri keuangan yang inklusif memiliki paling tidak tiga dimensi utama yaitu jangkauan (outreach), manfaat dan kualitas jasa keuangan (Sanjaya, 2015) . Indonesia menjadikan inklusi keuangan menjadi strategi nasional yang bertujuan untuk mendorong pertumbuhan ekonomi melalui distribusi pendapatan yang lebih merata, penurunan tingkat kemiskinan dan stabilitas sektor keuangan (Hadad, 2010). Dalam mewujudkan sistem keuangan yang inklusif tersebut, salah satu pilar yang penting adalah literasi keuangan sebagaimana yang juga telah dijadikan oleh Bank Dunia sebagai fokus (Universal Financial Access 2020, World Bank) yaitu pendidikan atau literasi keuangan disamping bagaimana memanfaatkan seoptimal mungkin teknologi dalam proses literasi tersebut. Menurut OECD:

"Financial Literacy (education) is the process by which financial consumer/investors improve their understanding of financial products and concept and through information, instruction and/or objective advice. Develop the skills and confidence to become more aware of financial risk and opportunities to make informed choices, to know where to go for help and to take other effective actions to improve their financial well-being." 
Tujuan dari literasi keuangan adalah menciptakan pengambilan keputusan ekonomi yang lebih baik melalui warga negara yang memiliki informasi dan pengetahuan yang memadai (Mishkin, 2008) dan juga untuk memperbaiki kesejahteraan rumah tangga (Sampson and Zia, 2009). Literasi keuangan dari sisi manfaat dapat dilihat dari diagram berikut ini:

Diagram 1. Manfaat dari literasi keuangan

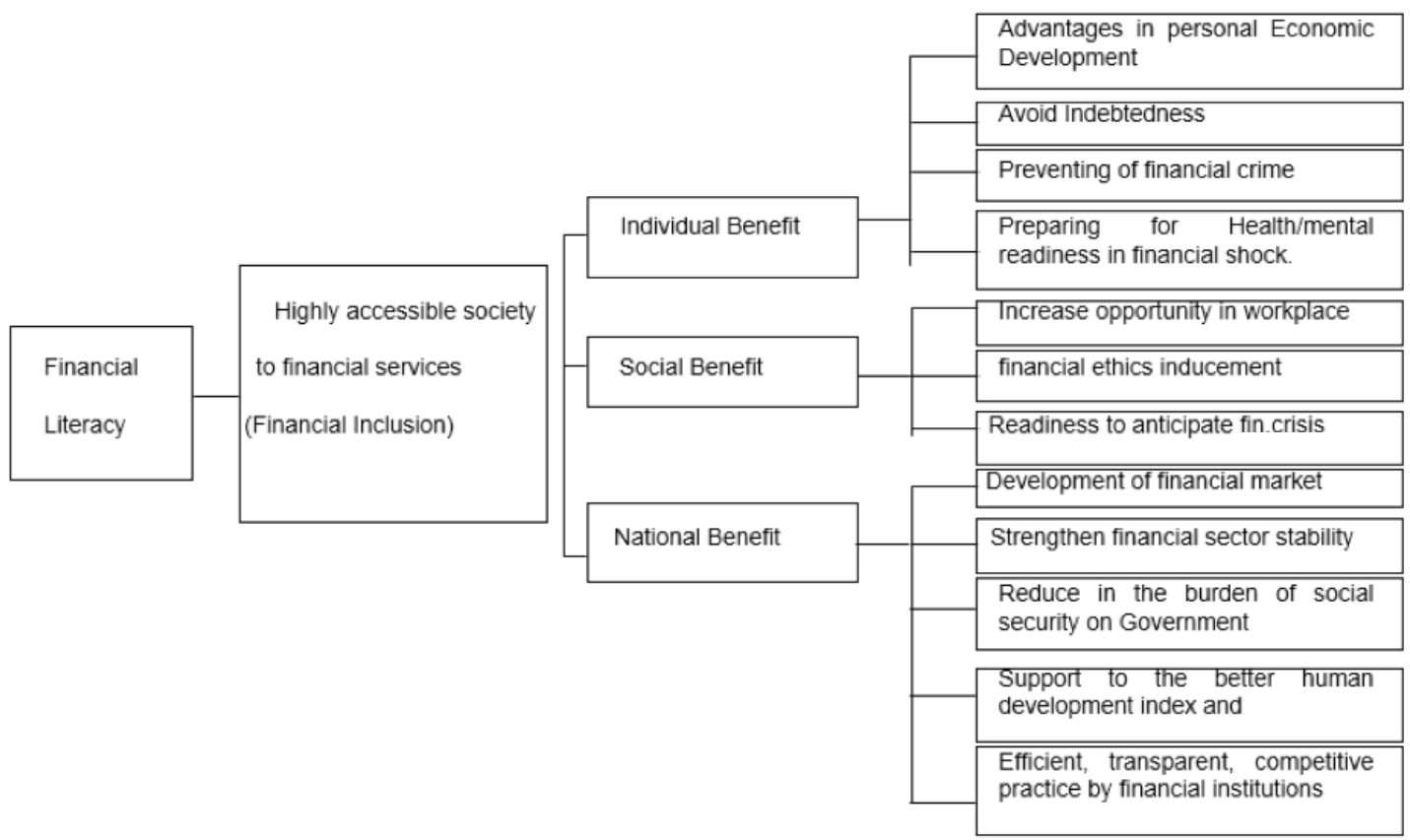

Sumber: Jariwala and Sharma, 2011, diolah.

Dari tujuan dan manfaat yang dapat diperoleh dari literasi keuangan, paling tidak telah menggambarkan tujuan adanya regulator sektor keuangan (dalam hal ini OJK) yang termuat dalam UU OJK No 21 tahun 2011 Pasal 4 dimana OJK hadir dengan bertujuan untuk mendukung pertumbuhan sektor keuangan secara sehat, meningkatkan tata kelola dan memperhatikan faktor keadilan dan meningkatkan kesejahteraan masyarakat. Tujuan dan manfaat ini seharusnya dapat terefleksikan dalam rancangan kebijakan.

\section{Literasi Keuangan dalam Perspektif Kebijakan Publik}

Kompleksitas Industri yang semakin tinggi dan Krisis keuangan yang intervalnya semakin pendek dari waktu ke waktu telah memaksa pemerintah di berbagai negara untuk melakukan penelaahan kembali berbagai kebijakan yang ada di sektor keuangan. Selama ini sebagian besar negara memfokuskan kepada "sisi penawaran (supply side)" dari kebijakan yang mana penekanannya adalah pada struktur organisasi, tata kelola, pengawasan yang hati-hati dan penindakan hukum ketimbang "sisi permintaan (demand side)" yang mana fokusnya lebih kepada kemampuan warga negara untuk memperkuat dirinya sendiri dari ancaman krisis (Jariwarla and Sharma, 2011).

Di dalam beberapa tahun belakangan, literasi keuangan telah memainkan peranan penting dalam reformasi keuangan global dan menjadi salah satu perangkat kunci kebijakan sektor keuangan di dunia (Zia and Xu, 2012). Laking dan Norman (2007) memberikan masukan bahwa kebijakan harus memiliki tiga tahapan krusial yaitu komitmen politik, mobilisasi inisiatif dan berkesinambungan. Cortazar dan Barzelay menawarkan kerangka kebijakan "Strategic functional point of view in public management process" yang mengajukan konsep bagaimana kebijakan manajemen publik dalam praktik terdapat ruang untuk dijadikan 
proses pembelajaran. Konsep ini mengadopsi pendekatan naratif (narrative approach) yang memungkinkan peneliti untuk menjadikan pengalaman-pengalaman kebijakan publik yang tingkat kompleksitasnya tinggi dijadikan referensi (benchmark) secara sistematis dengan harapan membuka ruang replikasi jika memungkinkan. Konsep ini terdiri dari pengembangan strategi (strategy development), implementasi strategi (strategy implementation) dan evaluasi untuk memastikan kesinambungan (lihat: diagram 2). Pendekatan ini telah digunakan oleh Social Development Institute pada Inter-American Development Bank dalam mempelajari praktik manajemen sosial di beberapa negara.

OECD adalah sebuah lembaga internasional yang merupakan sedikit dari mereka yang lebih memprioritaskan demand side dalam upaya memperkuat sektor keuangan melalui peningkatan kemampuan rumah tangga melalui pendidikan keuangan. Prioritas tersebut dianggap OECD dapat lebih efektif memperkuat sektor keuangan secara jangka panjang. Hipotesa yang diambil didukung oleh akademisi dalam berbagai studi. Bucher pada tahun 2010 menekankan bahwa ketidakcukupan tingkat literasi keuangan menjadi salah satu katalis dalam krisis keuangan. Peran dari literasi keuangan dalam melakukan mitigasi krisis ekonomi sangatlah penting (Olson, 2008) dan kemampuan untuk membuat keputusan keuangan yang benar sangat kritikal dalam menjaga stabilitas sektor keuangan terutama pada saat krisis (Klapper, Lusardi, Panos, 2011).

\section{Lingkungan Perubahan di Industri Keuangan (Etika, Kaum Muda dan Digitalisasi)}

Bagaimana mengedukasi lebih dari 100 juta kaum muda yang datang dari berbagai latar belakang keluarga, mereka akan menjalani beragam profesi dan menjadi calon pemimpin Indonesia di masa mendatang Tipologi kaum muda saat ini adalah mereka yang sangat tergantung dengan perangkat teknologi. Disamping itu pendekatan mendidik tidak cukup kepada upaya memberikan informasi ataupun mencerdaskan akan tetapi juga kepada induksi etika dan integritas dalam menyikapi fungsi uang dalam kehidupan sehari-hari.

Hal lain yang banyak disampaikan oleh pelaku pasar adalah bagaimana melibatkan lebih banyak platform teknologi karena selain teknologi dapat memungkinkan akses yang lebih terbuka kepada pendidikan sektor keuangan, dari sisi teori (Tapscott, 1994) maupun praktik juga dapat memangkas peran intermediary yang selama ini banyak menjadi sumber permasalahan tata kelola (governance), meningkatkan standardisasi secara lebih luas dan proses yang lebih efisien. Mckinsey dalam sebuah studinya memaparkan betapa teknologi telah merubah wajah dunia keuangan sedemikian rupa, tidak kurang dari 30 inovasi baru mewarnai industri keuangan saat ini.

Hal lain yang tidak kalah pentingnya adalah segmentasi literasi keuangan. OJK yang memayungi pendidikan komunitas di sektor keuangan yang bisa datang dari perbankan, pasar modal, asuransi, UMKM dan lain sebagainya. Pendekatan pendidikan keuangan tentunya tidak bisa berlaku umum tetapi diperlukan pendekatan yang berbeda sesuai dengan karakteristik industri dan mayoritas konsumen yang ada di dalamnya

Dan akhirnya di tengah tantangan tata kelola, kompetisi, sebagaimana yang diamanatkan oleh undang-undang, industri keuangan haruslah tetap bisa bertumbuh secara sehat. Sebuah cerita menarik dari Brazil dapat menjadi inspirasi dalam menumbuhkan pasar keuangan di tanah air dimana, pertumbuhan jumlah nasabah dipicu oleh banyaknya kelas pendidikan (baik class room maupun online) yang diadakan oleh regulator dan terutama oleh pelaku pasar.

\section{10 (Sepuluh) Tantangan Kunci}

Secara umum terdapat beberapa tantangan yang dihadapi oleh sektor keuangan dalam hal literasi keuangan, baik yang telah disampaikan oleh OJK sendiri (Wibowo, 2013) maupun yang telah disarikan dari pendapat beberapa pelaku pasar penting,

1. Perlunya komitmen politik yang kuat dari otoritas tertinggi dalam mengampanyekan strategi literasi keuangan yang menyeluruh.

2. Kolaborasi antara sesama pemangku kebijakan dalam pendidikan keuangan (Otoritas Keuangan, Sektor Swasta, Sektor Pendidikan, Media dan aparat penegak hukum).

3. Pentingnya memiliki target yang jelas dan organisasi yang khusus menjalankannya 
dengan struktur dan program yang berkesinambungan.

4. Integrasi pendidikan keuangan ke dalam kurikulum pendidikan secara keseluruhan.

5. Menyikapi situasi Oxymoron dalam integritas sektor keuangan sehingga dirasa penting induksi dari etika dan integritas melalui literasi keuangan.

6. Platform digital yang menjadi perangkat (tool) utama dalam literasi keuangan.

7. Segmentasi pendekatan pendidikan keuangan kepada beragam industri

8. Berbagi tanggung jawab dengan pelaku pasar dalam rangka mendidik masyarakat dengan langkah persuasif dan dalam kerangka menumbuhkan pasar.

9. Melibatkan diri pada kerjasama internasional (Policy Network)

10. Monitoring yang terus menerus terhadap semua inisiatif literasi keuangan.

\section{Literasi Keuangan: Pengalaman Beberapa Negara}

Melihat pengalaman negara lain dan melakukan pilihan yang cocok untuk penerapannya tidak dapat diragukan lagi menjadi salah satu hal terpenting di dalam domain kebijakan publik (Rose, 1993). Dalam pemaparan di makalah ini, ada beberapa negara yang dijadikan referensi karena diangap sebagai pemimpin dalam kampanye literasi keuangan. Australia dan New Zealand adalah yang paling awal melakukan inisiatif literasi keuangan secara menyeluruh. Sementara Brazil dan Singapura dianggap melakukan akselerasi yang paling progresif. (Jappelli, 2011). Dalam melihat Indonesia digunakan, "Functional View of Public Management" framework (Barzelay and Cortazar, 2004) sebagai referensi.

Diagram 2. A functional view of the public management process: financial literacy

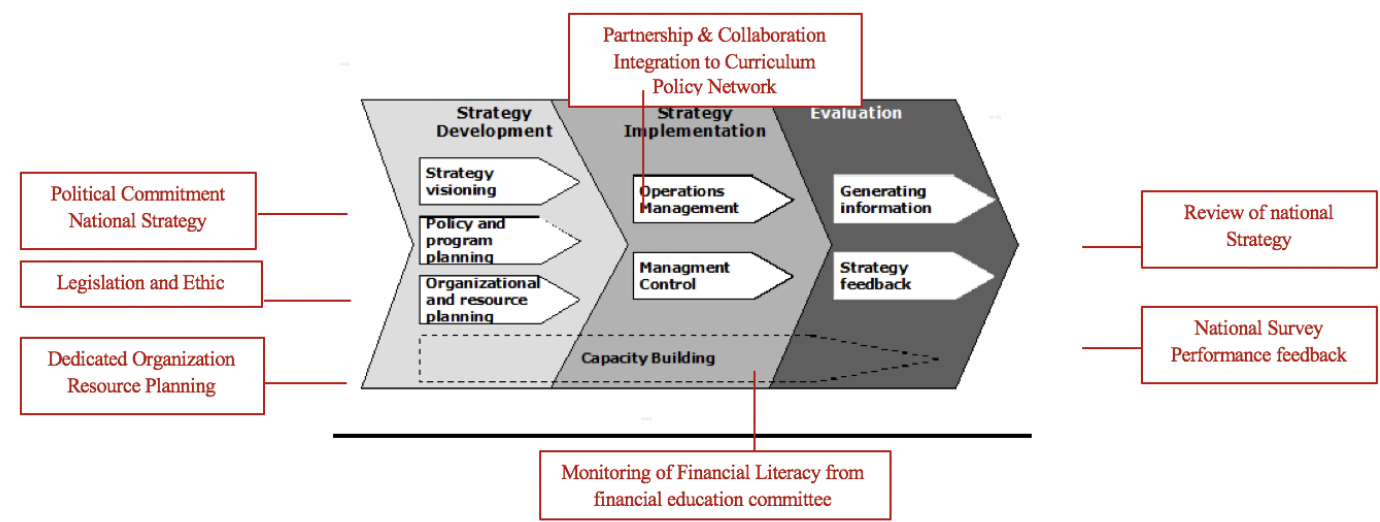

Sumber: Barzelay and Cortázar, chapter 3 of "Innovation in Governance \& Public Administration: Replicating what works, 2004

Berdasarkan kerangka perspektif di atas, strategi literasi keuangan dapat dielaborasi melalui penjelasan sebagai berikut:

\section{Tahap 1 : Pengembangan Strategi}

\section{Komitmen Politik dan Dukungan Legislasi}

Krisis keuangan global telah memberikan pesan terhadap pentingnya hubungan antara sektor keuangan, komitmen politik dan peraturan. Perdana Menteri Singapura, Lee Hsien Loong, adalah sosok yang memimpin langsung inisiatif pendidikan keuangan. Beliau menekankan bahwa warga Singapura perlu berpengetahuan dan berdaya tahan tinggi terhadap krisis. Pertemuan pemimpin-pemimpin negara dalam pertemuan tingkat tinggi G20 tahun 2012 di Rusia telah mengagendakan Financial Education sebagai salah satu fokus utama. Dari perspektif peraturan, untuk membangun kepercayaan diri dari dan rasa aman masyarakat, pemerintah Selandia Baru telah memberlakukan the Financial Service Providers (Registration and Dispute Resolution Act) pada tahun 2008. Regulasi-regulasi itu tidak saja mewajibkan pendidikan keuangan yang cukup tetapi juga melindungi warga jika terdapat pelanggaran-pelanggaran yang ada dalam pelayanan keuangan. 


\section{Strategi Nasional Literasi Keuangan}

Strategi Nasional penting untuk menetapkan arah jangka panjang dari kampanye literasi keuangan yang dilakukan dengan mengantisipasi beberapa perubahan lingkungan yang terjadi baik dari segi perubahan demografis, inovasi produk dan lain sebagainya. Telah terdapat 34 negara (OECD, 2015) yang telah mengimplementasikan strategi literasi keuangan. Indonesia belum lama telah menjadi salah satu di antaranya.

\section{Kelengkapan Organisasi dan Perencanaan Sumber Daya}

Pentingnya organisasi yang secara khusus menangani pendidikan keuangan sangat dibutuhkan untuk memenuhi harapan dari pemangku kebijakan (stakeholder). Selandia Baru menjadi salah satu negara pertama yang menyediakan dukungan literasi keuangan dengan membentuk Commission of Financial Literacy and Retirement Income, sebuah bentuk keseriusan yang menjadikannya acuan bagi negara lain (Crosan, 2010). Sementara itu di Singapura, inisiatif dilakukan oleh Money Sense, sebuah organisasi di bidang literasi keuangan berskala nasional dan dimonitor secara langsung oleh financial education steering committee.

\section{Membangun Karakter dan Integritas Komunitas Keuangan}

Membangun karakter dan integritas, menerapkan etika dan nilai yang proporsional terhadap fungsi uang dapat menjadi salah satu hal yang perlu dijadikan strategi unik Indonesia. Hal ini dilatarbelakangi oleh tingginya indeks persepsi korupsi yang mana korupsi terkait dengan penyalahgunaan uang menjadi salah satu sumber utamanya.

\section{Tahap 2 : Implementasi Strategi}

Kolaborasi (collaboration) dan Jaringan Kebijakan (policy network)

Kolaborasi yang menyeluruh diantara stakeholder dalam literasi keuangan menjadi salah satu keberhasilan Brazil dalam meningkatkan indeks literasi keuangannya. Di negara tersebut, fondasi kolaborasi dimulai dengan pembentukan Committee of Financial Systems, Capital Markets, Private Insurance and Social (COREMEC). Literasi keuangan menjadi topik utama yang diterjemahkan dengan pembentukan National Committee for Financial Education (CONEF). Kolaborasi dengan sektor swasta juga sangat strategis dengan pembentukan National Association for Financial Education (NAFE). Investimento, sebuah perusahaan asset management berbasis online telah berhasil menguasai pangsa pasar terbesar melalui education based sales model dimana KPI utama perusahaan tersebut adalah banyaknya kelas pendidikan yang diadakan untuk calon nasabah.

\section{Pengembangan Kurikulum Pendidikan Formal, Pemberdayaan Kaum Muda dan Inovasi}

Masyarakat perlu dididik tentang persoalan keuangan sedini mungkin. Alan Greenspan, mantan Gubernur Bank Sentral Amerika menyebut anak-anak di sekolah dasar sudah perlu diberikan informasi awal yang cukup mengenai keuangan. Australia telah menempatkan kurikulum yang terintegrasi dari usia dini (TK) dengan integrasi mata pelajaran keuangan dan yang lainnya (matematika, humanity dan kewarganegaraan). Brazil memperkenalkan inovasi financial soccer sebagai media pembelajaran yang efektif bagi penduduknya. SP Jain School of management akan menjadikan program pendidikannya mereka menjadi program Virtual Reality pertama di dunia pada tahun $2017^{5}$

\section{Tahap 3 : Monitoring, Evaluasi dan Umpan Balik}

Ada beragam bentuk evaluasi yang dapat dilakukan termasuk di dalamnya metaevaluation, internal, external, ex-ante, ex-post, rigorous, best practice (Wollmann, 2003). Makalah ini mengusulkan proses monitoring dilakukan berfokus pada internal dan melalui proses self-evaluation yang dilakukan oleh reviewer independen yang mengacu kepada best practice Selandia Baru dan Australia secara periodik melakukan review kepada strategi nasional mereka dan melaporkannya kepada pemerintah. Pada waktu-waktu tertentu dilakukan survei untuk memperoleh umpan balik atas proses yang telah dilakukan selama ini. 


\section{Penutup dan Beberapa Rekomendasi Kunci Untuk Indonesia}

Saat ini Indonesia kembali masuk ke dalam radar komunitas internasional sebagai salah satu negara yang paling menjanjikan di abad 21 baik dari kiprah dalam perekonomian dunia (G20), masuk ke radar investasi (Investment grade) dan potensi bonus demografi. Akan tetapi, hal yang tidak bisa ditunda adalah mempersempit gap pembangunan manusia dengan negara-negara lain. Beragam inisiatif telah dilakukan dalam pengembangan pembangunan sektor keuangan sebagai salah satu industri kunci pembangunan Indonesia. Dengan fokus pada pembentukan sektor keuangan yang inklusif, harapan untuk membangun komunitas sektor keuangan sebagai penunjang stabilitas sektor keuangan yang lebih kuat akan dapat terwujud.

Salah satu tantangan besar dalam mewujudkan pertumbuhan sektor keuangan yang inklusif adalah peningkatan literasi keuangan dan pembangunan karakter komunitas keuangan yang berintegritas tinggi. Momentum pembentukan OJK yang menjadikan literasi keuangan berada pada satu payung koordinasi adalah kesempatan besar yang dapat menunjang kepada tercapainya agenda-agenda di atas. Dalam periode lima (5) tahun pertama pembentukannya, inisiatif pendidikan keuangan telah dibangun fondasinya dengan baik, tergambar oleh bersentuhannya OJK dengan berbagai segmen dalam masyarakat yang selama ini menjadi target inklusi keuangan (masyarakat miskin, pekerja migran, nelayan, pensiunan, wanita) melalui beragam inisiatif termasuk "Ayo menabung" "laku pandai" (branchless-banking) ataupun Microfinance, persentuhan literasi keuangan dengan kurikulum pendidikan, penerbitan strategi nasional literasi keuangan yang dapat digunakan untuk memonitor perkembangan literasi keuangan (indeks literasi) dari waktu ke waktu. Dari sisi perlindungan konsumen, pembentukan satgas waspada investasi dan financial contact center juga telah banyak membantu masyarakat untuk berhati-hati dalam berinvestasi.

Ke depannya, berdasarkan kerangka functional view of public management berbagai inisiatif lanjutan dapat dikembangkan untuk mempercepat peningkatan literasi keuangan. Selain komitmen politik yang lebih besar, juga terutama yang berfokus pada peran OJK dalam memperluas cakupan target pendidikan, pembangunan karakter bangsa melalui pendidikan etika keuangan, perhatian khusus pada kaum muda dan pemanfaatan (leverage) platform digital dalam menggulirkan beragam inisiatifnya. Di samping itu juga perlu dipertimbangkan segmentasi pendidikan keuangan berdasarkan jenis sub- industri di dalam industri keuangan itu sendiri (perbankan, pasar modal, asuransi, dana pensiun, pegadaian, modal ventura dan lain sebagainya), pembentukan organisasi khusus yang menangani pendidikan keuangan ataupun perlindungan konsumen perlu untuk dikaji kelayakannya (seperti APRA di Australia), sinergi dengan pelaku pasar dalam memasalkan kewajiban mendidik masyarakat secara persuasif Dan juga inovasi-inovasi yang lebih memudahkan target pendidikan untuk ikut dan menikmati proses yang ada. Dari sisi perlindungan konsumen, peran yang lebih proaktif dapat diambil seperti penerbitan daftar negatif investasi dengan harapan dari awal semua warga negara memahami investasi dan seluruh karakteristiknya

Akhirnya, peran OJK di masa depan dari sisi pendidikan keuangan, tidak saja ada untuk mendidik, mencerdaskan, memberdayakan dan melindungi masyarakat atas manfaat dan risiko industri keuangan tetapi lebih besar lagi adalah kesempatan untuk membangun karakter berintegritas tinggi dari komunitas keuangan (masyarakat, konsumen, investor, pelaku paasar dan regulator) dan mempersiapkan generasi mendatang yang melek teknologi untuk lebih terlibat aktif dan mengambil peran dalam Industri keuangan. 


\section{Daftar Pustaka}

Claessens, S. (2006). Access to Financial Services: A Review of the Issues and Public Policy Objectives. The World Bank Research Observer 21(2): 207-238.

Commission for Financial Literacy and Retirement Income (2012). National Strategy for Financial Literacy. Wellington, CFLR.

Cortazar, J.M. (2006). Learning from Best Practice in Public Management: A Methodological Approach'pp'. in Bertucci (Ed), In Innovation in Governance and Public Administration: Replicating the Works. New York: United Nations.

Demirguc, A. and Klapper, L. (2012). Measuring Financial Inclusion in Global Findex Database, Policy Research Working paper 6021. Washington, World Bank.

Dubai Future Academy (2017). The State of The Future, Dubai Future Foundation.

Grifoni, A. and Messy, F. (2012) Current Status for National Strategy for Financial Education: A comparative Analysis and Relevant Practices. OECD Working papers on Finance, Insurance and Private Pensions, No.16, OECD Publishing.

Hamada, M. (2003) Transformation of the Financial Sector in Indonesia. IDS Research Paper No. 6, IDE-JETRO Publishing.

Jappeli, T. (2010). Economic Literacy: An International Comparison. The Economic Journal 120(11): 429-451.

OECD (2009). Financial Literacy and Consumer Protection: Overlooked Aspects of the Crisis. Paris, OECD.

Laking, R. and Norman, R. (2007). Imitation and Inspiration in Public Sector Reform: Lessons from Commonwealth Experiences. International Review of Administrative Sciences 73(4): 517-530.

Ministry of Public Finance (2010). National Strategy for Economic and Financial Education: A proposal for Implementation in Colombia. Bogota, Colombia.

Mukherjee, S. (2010). National Strategy for Financial Education in India. Paper presented in RBI-OECD Workshop on Delivering Financial Literacy.

Sanjaya (2015). Inklusi keuangan dan Pertumbuhan Inklusif; Analisia Antar Provisi di Indonesia. The 9th International Conference of Bulletin of Monetary Economics and Banking, Bank Indonesia

Taylor, S. and Wagland, S. (2011). Financial Literacy: A Review of Government Policy and Initiatives. AABFJ 5(2): 101-125.

Tapscott, D (1994). The Digital Economy: Promise and Peril in the age of Networkded Intellegence. McGraw-Hill, New York.

Vasco, Joe. (2010). The Brazilian Work on a National Strategy for Financial Education. Security and Exchange Commission of Brazil.

Visa International (2012). Visa International Financial Literacy, Barometer, Visa Practical Money Skills for Life.

Wibowo, P.(2013). Financial Education for Financial Inclusion: Indonesia Perspective. Jakarta: Bank Indonesia.

Xu, L. and Zia, B. (2012) Financial Literacy around the World: An overview of the Evidence with Practical Suggestions for the Way Forward, Policy Research Working paper 6107. Washington: World Bank. 